\title{
ALTERNATIVE MANAGEMENT OF MARINE TOURISM AREAS AT BANDENGAN WATERS, JEPARA, CENTRAL JAVA
}

\author{
(Alternatif Pengelolaan Area Wisata Laut di Perairan Bandengan, \\ Kabupaten Jepara, Jawa Tengah)
}

\author{
Juliana $^{1}$, Lachmuddin Sya' rani $^{2}$ dan Muhammad Zainuri ${ }^{2}$ \\ ${ }^{1}$ Politeknik Perikanan Negeri Tual. \\ ${ }^{2}$ Universitas Diponegoro Semarang.
}

\begin{abstract}
Bandengan waters have the potential to serve as a marine tourism area, its sustainability has to be preserved. Optimal utilization of Bandengan waters can provide benefits not only to the enxironment but also to the economic improvement of the community. Efforts to optimize marine tourism in Bandengan waters were conducted by reviewing area management alternatives to preserve and improve the welfare of the community. This study aims to analyze the alternative management of the marine tourism area using $\mathrm{A}^{\prime}$ WOT analysis which is a combined analysis of SWOT and AHP (Analytical Hierarchy Process) to establish strategies and to determine alternative management on marine tourism in Bandengan waters. Based on $\bar{A}^{\prime} W O T$ analysis obtained alternatives to manage marine tourism area which consists of spatial planning based on biophysical parameters, spatial planning based on the carrying capacity of the environment, increasing public and tourist awareness to cleanliness, improving both the quantity and quality of infrastructure, and the making of legislation. The recommended alternative management is basically aimed to preserve the marine tourism in Bandengan waters and to improve the people's welfare.
\end{abstract}

Keywords: marine tourism, alternative management, SWOT, AHP

Perairan Bandengan memiliki potensi yang dapat dijadikan sebagai kawasan wisata bahari, sehingga perlu dijaga kelestariannya. Pemanfaatan perairan Bandergan secara optimal dapat memberikan manfaat tidak hanya terhadap lingkungan tetapi juga terhadap peñíngkatan ekonomi masyarakat. Upaya untuk mengoptimalkan wisata bahari di perairan Bandengan dilăkukan pengkajian terhadap alternatif pengelolaan kawasan menjaga kelestarian dan meningkatkan kesejahteraan masyarakat. Penelitian ini bertujuan untuk menganalisa alternatif pengelolaan kawasan wisata bahari dengan menggunakan analisa A'WOT yaitu gabungan analisa SWOT dan PHA untuk menefapkan strategi dan menentukan alternatif pengelolaan kawasan wisata bahari di Perairan Bandengar. Berdasarkan analisa A'WOT diperoleh alternatif pengelolaan kawasan wisata bahari yang terdiri dari penatan ruang berdasarkan parameter biofisik, penataan ruang berdasarkan daya dukung lingkungan, peningkatan kesadaran masyarakat dan wisatawan terhadap kebersihan, peningkatan infrastruktur baik kuantitas maupun kualitas, serta pembuatan peraturan perundang-undangan. Alternatif pengelolaan yang dihasilkan páda dasarnya bertujuan untuk menjaga kelestarian kawasan wisata bahari di perairan Bandengan dan meningkatkan kesejahteraan masyarakat Bandengan.

Kata kunci: wisato bahari, alternatif pengelolaan, SWOT, AHP

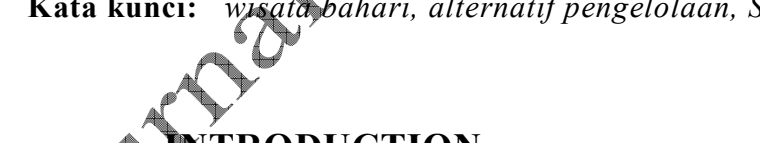

\section{INTRODUCTION}

Jepara is regency in the province of Centrab Java which is geographically located in coastal area. Most of the tourism relies on natural tourism potential of the panoramic beauty of the sea and the unique morphology of the coast. Bandengan waters are one of the coastal areas included in the district of Jepara. It used to be a very natural area with clear water and beautiful white sand, and the existence of coral reefs in the waters had bein attracting tourists to visit the Bandengan waters. However, the current water conditions are very different because it has been widely exploited by people around the waters. Condition of coral reefs is very alarming because it is in poor condition and almost no longer can be found.

If the potential of the tourism sector in the waters Bandengan be used optimally, then this sector can play an important role in efforts to accelerate economic development as a whole. The positive impacts will, not only on economic growth, but also to the expansion of employment opportunities, as well as tobe a source of considerable revenue potential for local goverment. The development of well managed Bandengan marine tourism also played a role in controlling various forms of environmental damage, especially since the coastal 
area is an area that is susceptible to various pressurs in the ecosystem.

The welfare of local people has not shown significant improvement despite the current exploitation of the Bandengan waters. This condition illustrates the need for efforts to manage Bandengan waters not only limited to physical exploitation of resources, but also the development of alternative resources to be utilized optimally and sustainably. This includes efforts to utilize the services of environmental and aesthetical value of the area for the development of marine tourism in order to obtain alternative sources of income and diversification of economic activities of local communities.

Development of the tourism sector is a part of be separated to do with sustainable development that has been announced by the Government in accordance with the national development goals. Sustainable development is not only related to environmental issues, but also is issues of democracy, human rights and other broader issues. Therefore, sustainable development is regarded as the best alternative development (Haris, 2003).

Based on the above phenomenon, it is necessary to study the alternative management of marine tourism in Bandengan waters, Jepara. The purpose of this study is to establish Bandengan waters alternative marine tourism management, in order to preserve the sustainability and to enhance the welfare of the community.

\section{METHODS}

The study was conductedon marine tourism in Bandengan waters. The type of data in this study consisted of primary data and secondary data. Primary data were obtained from observations, questionnaires, documentation and interviews directly in the field. The,respondents comprised of stakeholders envodved in the development of marine tourisun aetivities in Bandengan waters, Jepara. While secondary data is obtained from documents from varions departments or agencies in Jepara district.

Z) The number of respondents is 200 respondents. Determination of the respondents from bed resident, conducted by purposive sampling method base on the following criteria: 1) the respondent is a resident adult who at least has settled for 3 years in the Bandengan village, 2) residents who utilize coastal and marine resources in the Bandengan waters. Respondents from visiting tourists were selected through accidental sampling method. The samples selected were tourists who were on site at the time of the data collection, and considered to be mature enough and be able to give an answer that can be accounted for. Respondents from the government is selected by purposive sampling method on the basis that the respondent is an individual or institution that plays a role in the decision making in relation to the management of marine tourism in Bandengan waters, consisting of officials and staffs from Jepara Planning and Regional Development, the Department of Tourism, Department of Marine and Fisheries, and the Department of Transportation.

The method of data analysis by using the combination A'WOT SWOT analys (Rangkuti, 2002) and the Analytical Hierarchy Process (AHP) based on Saaty (1993). SWOT analysis is done by preparing internal factors and external in Bandengan waters which will be submitted to the respondent to make an assessment. The scores given to each of the external and internal factors are the same, ranging from $0, \theta$ (not important) till the 1 (very important). Seoring depends on the impact of these factors, and the total of the score should be equal to 1 . While -4 scale used for rating, is 1 (very important), 2 (important), 3 (unimportant), and 4 (very unimportant). Ratings are also given based on the level of importance of these factors. After compilation of external factors and internal factors, four sets of possible strategies, the SO, ST, WO, and WT strategies, were prepared.

The four sets of strategies are analyzed by using AHP, in order to obtain an alternative that will be applied to the management of marine tourism in Bandengan waters, Jepara. To quantify qualitative data, scale pairwise comparisons according to Saaty (1993), as in Table 1, were used.

Table 1. The scale of appeals in pairs.

\begin{tabular}{|c|c|}
\hline Importance & Definition \\
\hline 1 & Both elements are equally important \\
\hline 3 & $\begin{array}{l}\text { One element is a bit more important than } \\
\text { the other elements }\end{array}$ \\
\hline 5 & $\begin{array}{l}\text { One element is essential or very important } \\
\text { compared to the other elements }\end{array}$ \\
\hline 7 & $\begin{array}{l}\text { One element is obviously more important } \\
\text { than the other elements }\end{array}$ \\
\hline 9 & $\begin{array}{l}\text { One element is absolutely more important } \\
\text { than the other elements }\end{array}$ \\
\hline $2,4,6,8$ & $\begin{array}{l}\text { values between two adjacent } \\
\text { considerations }\end{array}$ \\
\hline Inversion & $\begin{array}{l}\text { If activity } i \text { got one point when compared } \\
\text { to activity } j \text {, then } j \text { has the opposite value } \\
\text { when compared to activity } i \text {. }\end{array}$ \\
\hline
\end{tabular}

\section{RESULTS AND DISCUSSION}

Determination of alternative marine tourism management in Bandengan waters begins by de- 
termining the internal and external factors by using SWOT analysis. Management strategy in the management of marine tourism in Bandengan waters through SWOT analysis, which identifies the internal factors (strengths and weaknesses) and external factors (opportunities and threats) that affect the management of marine tourism. Internal and external factors on marine tourism in Bandengan waters consist of four factors of strengths, nine factors of weaknesses, four factors of opportunities and four factors of threats (Table 2).

A clearly descriptive strategy of how the external factors such as opportunities and threats faced in the management of marine tourism in Bandengan waters can be adjusted by internal factors and external factors which they own. There are four sets of strategies that can be formed, are:

\section{SO Strategy}

SO strategy was create using the existing strengths to take advantage of the available opportunities that present in Bandengan waters. SO strategies were created then calculated to determine the order of strategies (Table 3).

\section{ST Strategy}

ST strategy was made using the existing strength to overcome the threat in the tourist area of Bandengan waters. ST Strategies created then their scores calculated to determine the order as obtained from the ST strategy respondents (Table 4).

\section{WO Strategy}

WO strategy is based on the use of the opportunities that are possessed by minimizing weaknesses found in marine tourism in Bandengan waters. WO Strategies created and their dores were calculated to determine the order as gbtamed from WO strategies respondents (Table 5).

\section{WT Strategy}

WT strategies were based on the attempts that try to minimize yeaknesses and avoid threats. WT strategies created and scores then calculated to determine the isequence as obtained from WT strategies respondents (Table 6).

Table 2. Internal and external factors of management in Bandengan marine tourism, Jepara.

\begin{tabular}{|c|c|}
\hline Internal Factors & External Factors \\
\hline $\begin{array}{l}\text { Strength } \\
\text { 1. The location is strategic and is adjacent to several other tourist } \\
\text { 2. Bandengan waters have a wide stretch of white sand } \\
\text { 3. The society wants to make Bandengan waters as marine tourism area } \\
\text { 4. The availability of human resources that could potgntially be man power }\end{array}$ & $\begin{array}{l}\text { Opportunities } \\
\text { 1. The increasing number of tourists } \\
\text { 2. Increased income and welfare } \\
\text { 3. Expanding employment opportunities } \\
\text { for the community } \\
\text { 4. Increasing local revenue }\end{array}$ \\
\hline $\begin{array}{l}\text { Weakness } \\
\text { 1. Utilization of space does not pay attention to the carrying capacity of the } \\
\text { environment } \\
\text { 2. Community and tourist awareness the cleanliness and preservation of } \\
\text { environment is still low } \\
\text { 3. Low level of public education } \\
\text { 4. Limitations of venture capital } \\
\text { 5. Limited facilities and infrastructure to support marine tourism activities } \\
\text { 6. The absence of regutations concerning the management of a tourist area. } \\
\text { 7. Economic level of the people is still low } \\
\text { 8. The government is rot optimal in managing marine tourism } \\
\text { 9. Promotion of marine tourism in the region is very limited waters Bandengan }\end{array}$ & $\begin{array}{l}\text { Threat } \\
\text { 1. Environmental degradation } \\
\text { 2. Increased domestic waste } \\
\text { 3. Rivalry among investors from outside } \\
\text { of the Bandengan community } \\
\text { 4. Investor interest is high }\end{array}$ \\
\hline
\end{tabular}

Table 3. The value of SO strategy in the management of marine tourism in Bandengan waters.

\begin{tabular}{|c|c|c|c|c|c|c|c|}
\hline & \multirow{2}{*}{ SO Strategies } & \multicolumn{4}{|c|}{ Response } & \multirow{2}{*}{ Average } & \multirow{2}{*}{$\begin{array}{l}\text { Rating } \\
\text { Score }\end{array}$} \\
\hline & & 1 & 2 & 3 & 4 & & \\
\hline & $\begin{array}{l}\text { The development of marine tourism activities by creating tourist facilities } \\
\text { on land such as construction of water boom }\end{array}$ & 31 & 26 & 54 & 89 & 3.01 & 75.13 \\
\hline 2. & Provision of working capital & 30 & 32 & 48 & 90 & 2.99 & 74.75 \\
\hline 3. & Human resources training & 43 & 31 & 34 & 92 & 2.88 & 71.88 \\
\hline
\end{tabular}

Table 4. The value of ST strategy in the management of marine tourism in Bandengan waters.

\begin{tabular}{|c|c|c|c|c|c|c|c|}
\hline \multirow{2}{*}{ No. } & \multirow{2}{*}{ ST Strategies } & \multicolumn{4}{|c|}{ Response } & \multirow{2}{*}{ Avarage } & \multirow{2}{*}{$\begin{array}{l}\text { Rating } \\
\text { Score } \\
\end{array}$} \\
\hline & & 1 & 2 & 3 & 4 & & \\
\hline 1. & $\begin{array}{l}\text { Spatial planning for marine tourism activities based on biophysical } \\
\text { parameters }\end{array}$ & 21 & 13 & 78 & 88 & 3.17 & 79.13 \\
\hline 2. & $\begin{array}{l}\text { Provision of facilities and infrastructure to accommodate domestic wastes } \\
\text { as the result of tourism activities }\end{array}$ & 22 & 32 & 64 & 82 & 3.03 & 75.75 \\
\hline
\end{tabular}


Table 5. The value of WO strategy in the management of marine tourism in Bandengan waters.

\begin{tabular}{|c|c|c|c|c|c|c|c|}
\hline \multirow{2}{*}{ No } & \multirow{2}{*}{ WO Strategies } & \multicolumn{4}{|c|}{ Response } & \multirow[b]{2}{*}{ Average } & \multirow{2}{*}{$\begin{array}{l}\text { Rating } \\
\text { Score }\end{array}$} \\
\hline & & 1 & 2 & 3 & 4 & & \\
\hline 1. & $\begin{array}{l}\text { Spatial planning for marine tourism activities based on the carrying } \\
\text { capacity of the environment }\end{array}$ & 18 & 42 & 43 & 97 & 3.10 & 77.38 \\
\hline 2. & $\begin{array}{l}\text { Increased public awareness and tourists of the importance of cleanliness } \\
\text { and the environment }\end{array}$ & 23 & 34 & 56 & 87 & 3.04 & 75.88 \\
\hline 3. & Training and education for the community to improve their skills & 27 & 34 & 64 & 75 & 2.94 & 73.38 \\
\hline 4. & Rulemaking regarding the management and utilization of marine tourism & 42 & 21 & 65 & 72 & 2.84 & 70.88 \\
\hline 5. & Improved infrastructure which supports marine tourism area & 28 & 32 & 56 & 84 & 2.98 & 74.50 \\
\hline 6. & Increased promotion of nautical tourism & 32 & 56 & 77 & 35 & 2.58 & 64.38 \\
\hline
\end{tabular}

Table 6. The value of WT strategies in the management of marine tourism in waters Bandengan.

\begin{tabular}{|c|c|c|c|c|c|c|}
\hline \multirow{2}{*}{ No } & \multirow{2}{*}{ WT Strategies } & \multicolumn{4}{|c|}{ Response } & \multirow{2}{*}{ Averagé $\begin{array}{c}\text { Rating } \\
\text { Seore }\end{array}$} \\
\hline & & 1 & 2 & 3 & 4 & \\
\hline 1. & Rehabilitation and remediation of areas & 47 & 53 & 47 & 53 & 63.25 \\
\hline 2 & Conservation & 54 & 63 & 56 & 27 & 57.00 \\
\hline 3. & $\begin{array}{l}\text { Increasing the role of society and government in the management and } \\
\text { supervision of marine tourism }\end{array}$ & 34 & 54 & 45 & & 68.13 \\
\hline
\end{tabular}

Based on the result of SWOT analysis, AHP analysis was conducted to determine management alternatives. Results obtained from the analytical hierarchy process for the management of marine tourism in Bandengan waters showing a score in Figure 1.

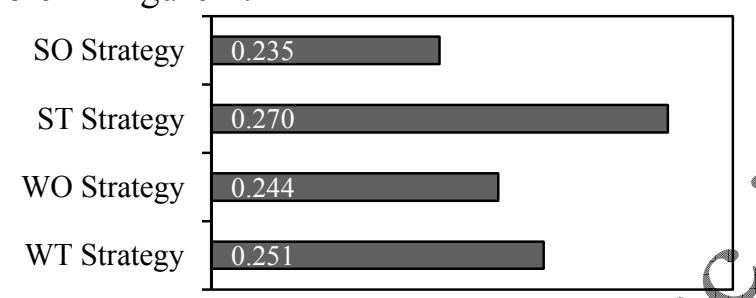

Figure 1. The results of analytical hierarchy process alternative management of marine tourism in Bandengan waters

After obtaining the scores on each of the strategy contained in the SWOT the score is multiplied in any strategy to determine the order of priority of the strategies in the management of marine tourism in Bandengan waters. Among the four groups of strategy contained in the SWOT analysis which were analyzed by analytic hierarchy process, ST strategy is the first priority, followed by WO strategy as the second priority, the ST strategy as the third priority, and WT strategy as the fourth priority (Table 7).

Table 72 The results AHP analysis on the strategies for marine tourism Zone Management.

\begin{tabular}{ccccc}
\hline Strategies & $\begin{array}{c}\text { Score } \\
\text { (S) }\end{array}$ & $\begin{array}{c}\text { Quality } \\
\text { (Q) }\end{array}$ & S x Q & Priority \\
\hline SO & 73.92 & 0.235 & 17.37 & 3 \\
ST & 77.67 & 0.270 & 20.97 & 1 \\
WO & 72.73 & 0.244 & 17.75 & 2 \\
WT & 62.79 & 0.251 & 15.76 & 4 \\
\hline
\end{tabular}

Based on the results of the SWOT and the AHP analysis, Table 8 presented the top five prio- rities of alternatives in the management of marine tourism in Bandengan waters. The first alternative is spatial planning for marine tourism activities based on biophysical parameters (21.37). Marine tourism activities are heavily influenced by biophysical waters which serve as a marine tourism. That the biophysical parameter measurements in water ean te used as an indicator to determine the devel of contamination that occurred on waters. Elyazar et al. (2007), states that the pollution can be caused by the activity of hotels, restaurants, - household waste and fishermen who normally dispose toxic waste into the waters. This indicates that the spatial arrangement based on waters biophysical parameters of marine tourism in Bandengan waters is very necessary to prevent pollution due to uncontrolled tourism activities.

Table 8. The five priorities of management of marine tourism in Bandengan waters.

\begin{tabular}{clc}
\hline No & \multicolumn{1}{c}{ WO Strategies } & Score \\
\hline 1. & $\begin{array}{l}\text { Spatial planning for marine tourism activi- } \\
\text { ties based on biophysical. }\end{array}$ & 21.37 \\
2. & $\begin{array}{l}\text { Spatial arrangement of marine tourism acti- } \\
\text { vities based on the carrying capacity. }\end{array}$ & 20.45 \\
3. & $\begin{array}{l}\text { Increasing the public awareness of hygiene } \\
\text { and environmental quality. }\end{array}$ & 18.88 \\
4. & $\begin{array}{l}\text { Improvement of infrastructure. } \\
\text { 5. }\end{array}$ & $\begin{array}{l}\text { Regulations regarding the management and } \\
\text { utilization of marine tourism. }\end{array}$ \\
\hline
\end{tabular}

The second alternative is the arrangement of space for marine tourism activities which is based on the carrying capacity of the environment (20.45). Environmental carrying capacity is the maximum number of visitors that can physically be accommodated in an area that has been provided at any given time without causing disturbance to the environment and people around it (Yulianda, 2007). Environmental carrying capacity on tourist 
areas is the level of visitors who utilize a tourist area with the acquisition of an optimal level of satisfaction with a minimal impact on resources. This concept includes two major factors that limit the behavior of visitors associated with the carrying capacity of the environment and social and cultural conditions (Sinurat, 2000). Tourism carrying capacity indicates the maximum level of visitor which uses and relates to the infrastructure that can fit an area. If the carrying capacity is exceeded, this would result in the deterioration of resources, reduced visitor satisfaction and or adverse impact on social and economic aspects. By these definitions ensure the sustainability of marine tourism in Bandengan waters, marine spatial planning needs to be done based on the carrying capacity of the environment.

The third alternative is to increase public awareness of the importance of hygiene and environmental rating (18.88). Cleanliness is a factor that can lead to higher pollution in an area. Bandengan waters as a tourist area produces a lot of waste as a result of tourism activities. Garbage dumping which is done carelessly results in environmental damage. Indiscriminate waste disposal also negatively impact the beauty of the environment and cause inconvenience for travelers. Communities and travelers should be informed about how to manage and dispose of waste properly. According to Monoarfa (2002), pollution can disrupt tourists and damage the environment, so the pollution on marine tourism area needs to be minimized.

The fourth alternative is the improvement of infrastructure for marine tourism (18.51). Existing infrastructure in the area of marine tourism in Bandengan waters is still very mínimal. Facilities and infrastructure such as roads, boat tours, banana boat and jet ski used on marine tourism in Bandengan waters are low in both quantity and quality aspects. Infrastructure is very influential on the attractiveness of a marine tourism.

The fifth alternative is rulemaking regarding the management and utilization of marine tourism (18.18). Jepara regency government is not optima jn managing marine tourism in Bandengan waters. This is proven by the absence of local regulations that govern the management and utilization of marine tourism. Regulation is necessary to maintain the sustainability of the region, especially with the sanction given when managers, visitors and the public break the rules that can result in environmental damage.
Management of marine tourism should pay attention to the balance and sustainability of the region. This is also supported by the opinion Kusumastanto (2000) which state that the policy of marine tourism is mainly directed to:

1. Increase the availability of public facilities to create services and conveniences for domestic and foreign tourists who will utilize the resources of marine tourism.

2. Improve the quality and capacity of human resources role in managing marine tourism.

3. Develop a data collection system and complete information by utilizing modern toehnology, making it easier to get information and access it quickly, cheaply and easily Data collection and information system development is both to serve and support the promotion and investment in marine tourism.

4. Developing non-tourism economic activities that are relevant to marine tourism activities, such as craft industriès, fisheries, sea food restaurants and ocean freight services.

5. Improve security and safety system for travelers who utilize the potential of marine tourism.

6. Creating a conducive investment climate for investors to develop marine tourism as an incentive or disincentive.

Develop a marine tourism management model which is capable of conserving marine ecosystems and the local culture.

Management of marine tourism should maintain the characteristics of the existing ecosystems because, according to Wheat (1994) and Steel (1993) in Gusti (2011), marine tourism is a niche for people who are aware of the environment and interested in the nature and marine tourism. It is an economic process which markets attractive and rare ecosystems.

Based on the above opinion, the alternative management of marine tourism in Bandengan waters should take advantage of the natural resources that exist at present optimally and should also pay attention to the sustainability of the region in the long term in order to be enjoyed by generations to come. Spatial planning, improvement of facilities and infrastructure, human resources as well as legislation that would set out in the management of marine tourism in Bandengan waters should optimize the existing natural resources by taking into account the preservation and sustainability of the marine tourism. 

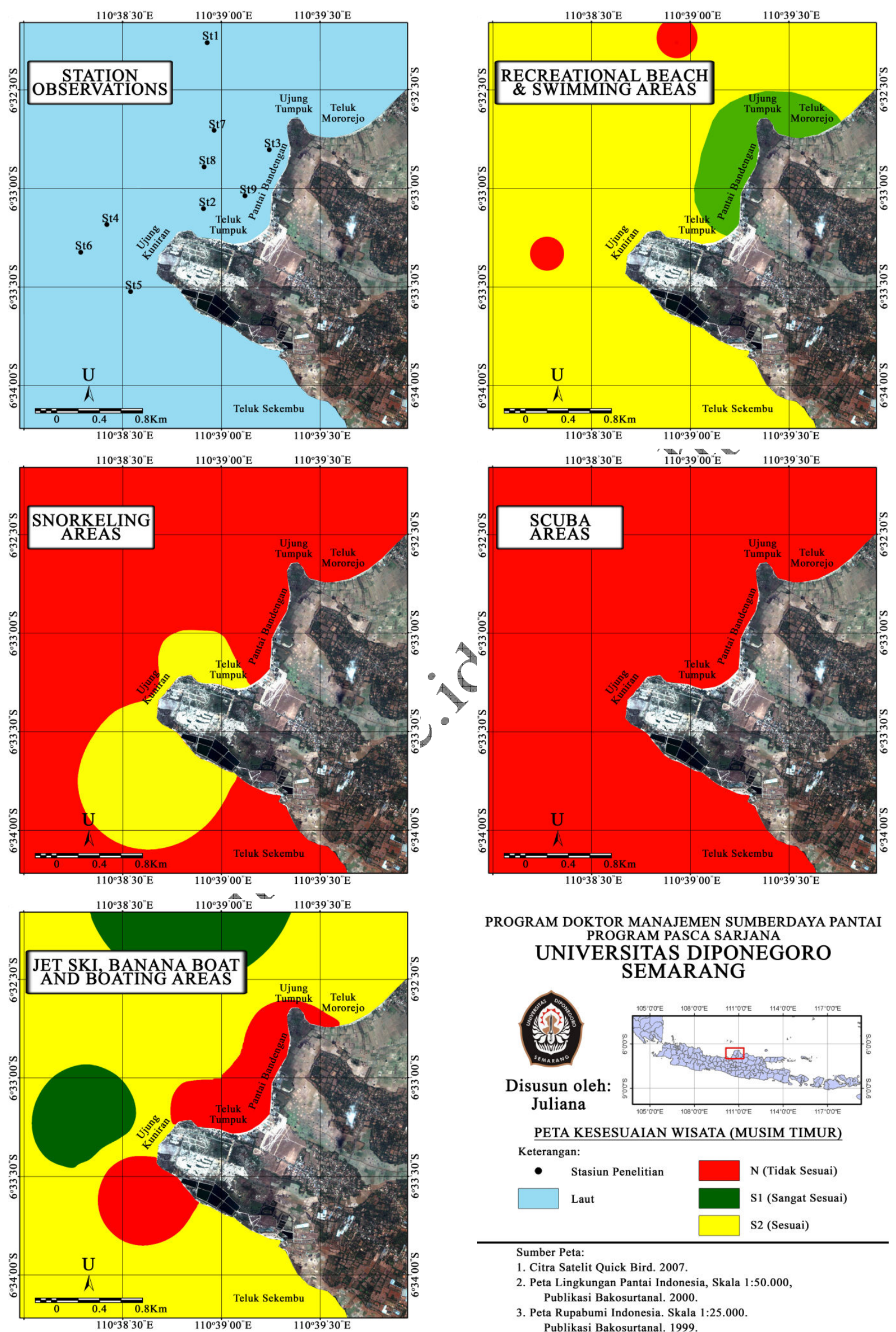

\section{PROGRAM DOKTOR MANAJEMEN SUMBERDAYA PANTAI PROGRAM PASCA SARJANA UNIVERSITAS DIPONEGORO SEMARANG}

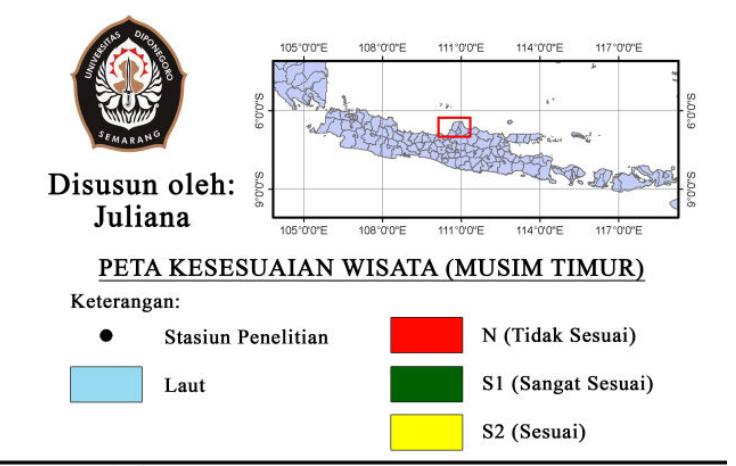

Sumber Peta:

1. Citra Satelit Quick Bird. 2007.

2. Peta Lingkungan Pantai Indonesia, Skala 1:50.000, Publikasi Bakosurtanal. 2000.

3. Peta Rupabumi Indonesia. Skala 1:25.000. Publikasi Bakosurtanal. 1999. 


\section{CONCLUSION}

Based on the analysis of A'WOT the factors that affect marine tourism in Bandengan waters, there are four sets of strategies which are SO, ST, WO, and WT strategies. Based on the four sets of strategies and AHP analysis results in alternative management of marine tourism.

\section{REFERENCES}

Elyazar N, MS Mahendra and IN Wardi. 2007. The Impact of Community Activity Against Sea Level Air Pollution in Kuta Badung And Environmental Conservation Efforts. Ecotrophic, 2(1): 1-18.

Gusti Agung Gede Oka Gauthier I. 2011. The Evaluation of Marine Tourism Development at Sanur Beach. Thesis Master's Program Assessment Study of Tourism. Graduate Program, University of Udayana, Denpasar. 242 p.

Haris A. 2003. Land Suitability Analysis and Land Use Policy in the Gulf Coastal Kayeli Buru regency. Graduated Program Thesis, Bogor Agricultural University.
Kusumastanto T. 2000. Planning and Development of Small Islands. Workshop on Spatial Approaches in the Development of Coastal Areas, Coastal and Small Islands. P3K Directorate, Ministry of Marine Affairs and Fisheries. Jakarta, Indonesia.

Monoarfa W. 2002. Construction Impacts to Water Quality in Coastal Regions of Losari Makassar. Science and Technology, 3 (3): 37-44.

Rangkuti F. 2002. SWOT Analysis Technique Dissecting the Business Case. Publisher PT. Scholastic Press, Jakarta. 188 p.

Saaty, 1993. Decision Making for Leaders. Translation. Publ. PT. Binaman Library, Jakarta. 268 p.

Sinurat MR. 2000. Institutional Analysis of the Management of Coastal Resources in the Eastern Coastal Wetlands Sragi South Lampung regency. Thesis, Bogor Agricultural University.

Yulianda F. 2007. Marine Ecotourismas an Alternative Utilization Resource Conservation Based. Science Standards Department of Water Resources Management. Faculty of Fisheries and Mayine Science, Bogor Agricultural University.

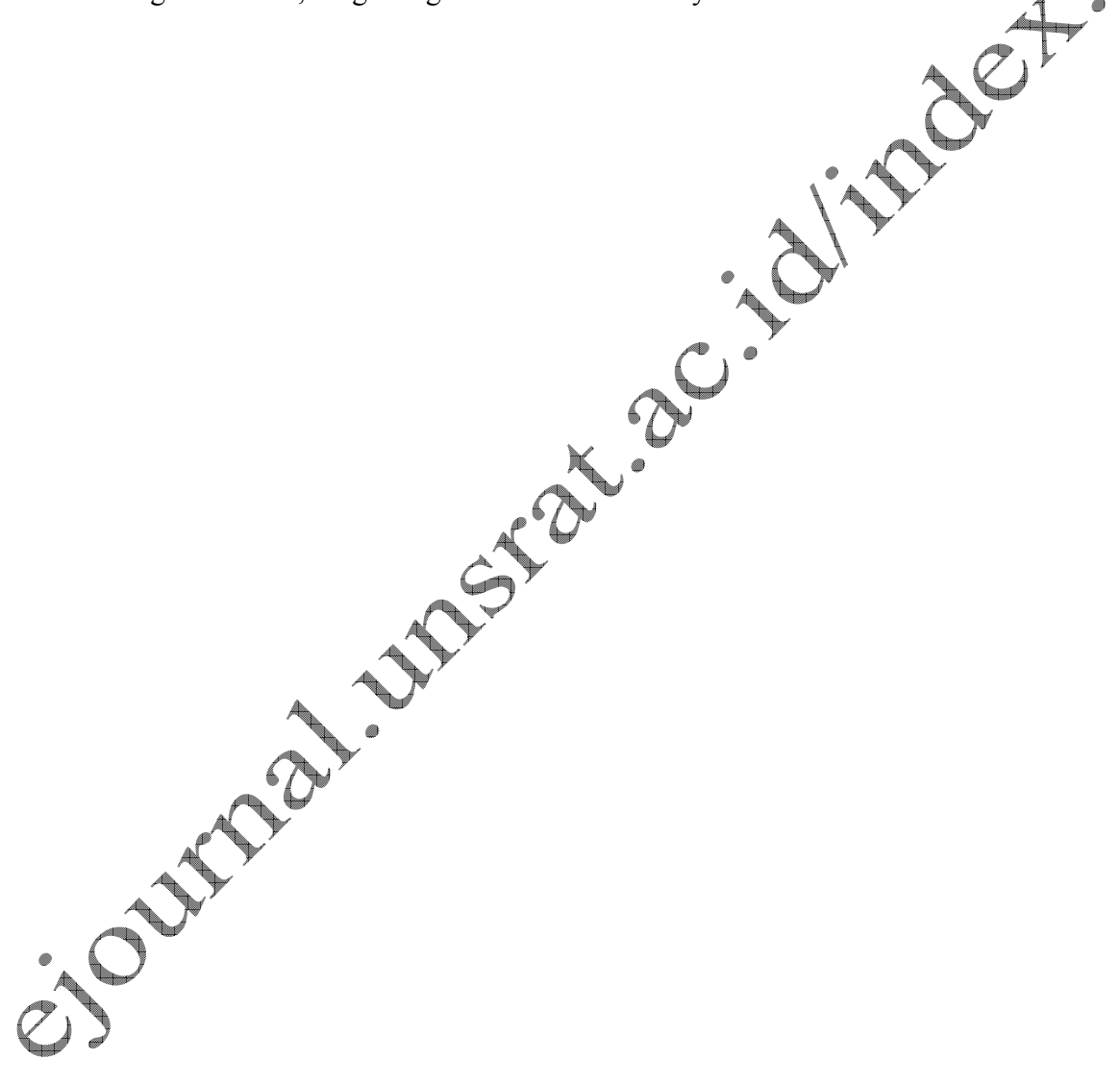

